DOI: http://doi.org/10.21698/simi.2018.ab32

\title{
DETECTION OF SALMONELLA SPECIES FROM ARGES RIVER
}

Veronica Panait, Florentina Iarim, Cristina Mirea

Apa Nova Company, 7 Intrarea Crinului Street, Bucharest, Ilfov County, veronica.panait@veolia.com,Romania

Keywords: microbiological detection,Salmonella, surface water

\section{Introduction}

The surface water suffer a lot a modification beacause human activities. Monitoring these water sourcesrepresents an important thing. The study present the identification of Salmonella species from Arges river. Salmonellosis is an infection caused by the bacteria called Salmonella, which has been known to cause illness for more than 100 years. Salmonella may be found in water sources such as private wells that have been contaminated with the feces of infected human or animals. Waste can enter the water throught different ways, including sewage overflows, polluted storm water ruoff and agricultural runoff. The monitoring was performed in 2018, started with January, the analizes was performed monthly. In order to see the influence of physico-chemical factors, the variation of $\mathrm{pH}$, the turbidity of water, as well as weather conditions (temperature) were followed.

\section{Materials and methods}

The analyzis method is the same with ISO 19250:2013- „Water Quality- Detection of Salmonella spp." The confirmation test was performed using Api 20 E. Additional tests consisted of serological confirmation and qualitative enzymatic tests, performed using kits Singhlepath Salmonella. The materials, the methodical determinations and the results are presented. The results are expres in accordarce with the results of the biochemical tests and serological confirmation, indicate whether presumtive or confirmed Salmonella.

The aparatus used are calibrated according romanian legislation. The culture media provider is BioMeriux. The serological tests are supllied from Magesa.

\section{Results and conclusions}

Salmonella sp. analyses were performed monthly on $1000 \mathrm{ml}$ sample in this year. The sample was concentrate by filtration process using $0.45 \mu \mathrm{m}$ cellulose membranes. It was obtained presumptive positive colonies each month. In only two from five analyzes the biochemical test showed a good identification of the Salmonella, the other have revealed the presence of $99.5 \%$ Proteus mirabilis from RapportVassiliadis broth at XLD plates (xylose lysine deoxycholateagar) - in Januarie, 99.4\% Photobacterium damselae from MKTTn broth (Muller-Kauffmann tetrathionatenovobiocin broth) at Rambachplates in February and 99.8\% Raoultella ornitinolytica from Rapport-Vassiliadis broth at Rambach plates in April. The presence of Salmonella is influenced only the water turbidity. 


\section{INTERNATIONAL SYMPOSIUM "THE ENVIRONMENT AND THE INDUSTRY", SIMI 2018, BOOK OF ABSTRACTS}

The experimental results are present in the table and figures below:

Table 1. Experimental results

\begin{tabular}{lccccc}
\hline Month & January & February & March & April & May \\
\hline Turbidity[NTU] & 48.2 & 116.2 & 432.7 & 129.3 & 166.4 \\
\hline $\mathrm{pH}\left[\mathrm{H}^{+}\right]$ & 8.04 & 8.07 & 7.98 & 7.98 & 8.02 \\
\hline Temperature $\left[{ }^{\circ} \mathrm{C}\right]$ & 2.95 & 3.68 & 5.05 & 14.68 & 19.61 \\
\hline Salmonellasp. $[\mathrm{P} / \mathrm{A}]$ & Absent & Absent & Present & Absent & Present \\
\hline
\end{tabular}

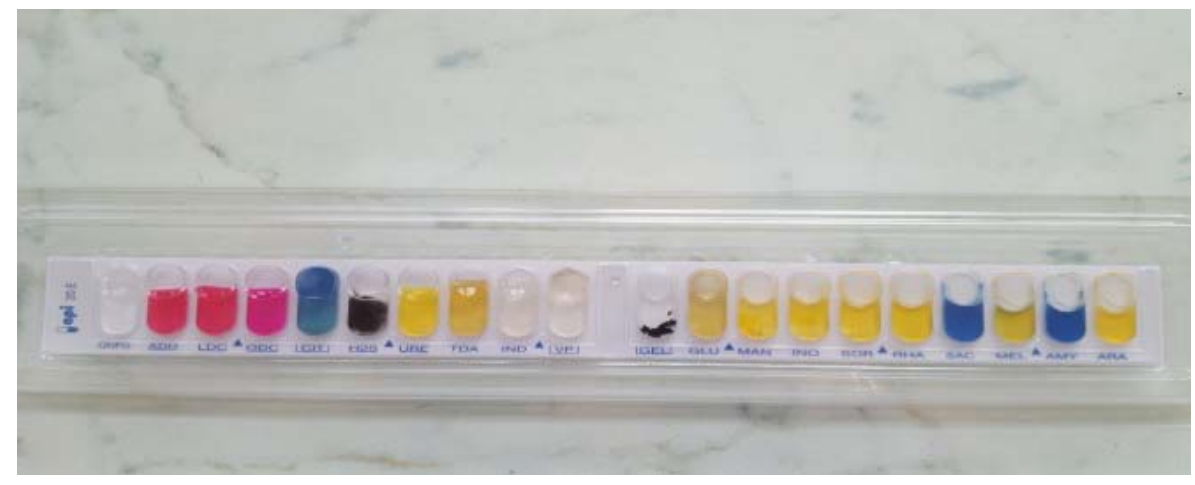

Figure 1. Api 20 E Test with positive Salmonella

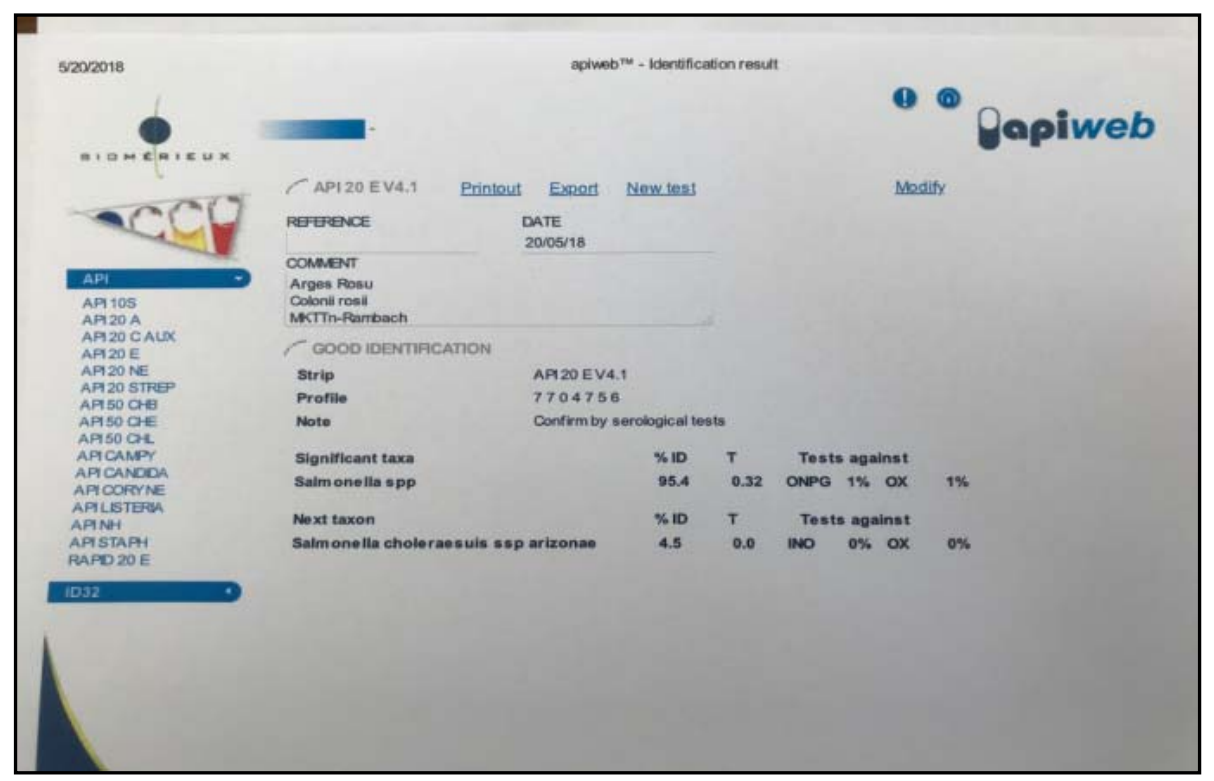

Figure 2. Interpretation of the result with Apiweb 